\title{
Readiness of senior higher school students for self- determination in ecology field as an ability to form subjective attitude
}

\author{
Evgeny V. Titov ${ }^{1}$, and Evgeny I. Cherkashin ${ }^{2, *}$ \\ ${ }^{1}$ BMSTU, Department of ecology and indusrial safety, 105005, Moscow, Russia \\ ${ }^{2}$ ISED RAE, Center of Supplementary Education and Carrier-Guiding of Learners, 105062, Moscow, Russia
}

\begin{abstract}
The current state of environment demands from senior pupils to occupy a correct position in problem ecological situations. An effective means of forming senior pupils' own position is activity in a field of ecology. Through a variety of activities in the field of ecology (learning, playing, research, environmental protection, and others.) senior pupils are involved in situations requiring self-determination. Self-determined senior pupils overcome a conflict, a contradiction between an individual's position and a social role caused by a situation arising in activity.
\end{abstract}

Modern society is in a condition of a deep crisis which can be considered as a set of essential changes of form and content of social ties and relations. These changes have affected all spheres of society. They involved all social and age groups, including the young generation entering into independent life. School graduates don't have the social experience and join as subjects of activity in diverse problem situations on which permission their vital, professional and emotional and valuable choice, and, in general, destinies of society depend.

The current stage of development of society can be defined as a crisis, which is characterized by aggravation of a number of contradictions that displayed in the form of diverse problem situations that require a creative and active approach to their solution from the younger generation, based on a personal position in the field of ecology. The establishment of the social institution that provides the society with a decent level of ecological safety is being observed for last decades. It is evident from the development of sectors of the economy, politics, law and supplement branches of science, aimed at satisfying ecological requirements. As a matter of fact, it is appropriate to state the appearance of a stable area of social relations that is ecological one, within which the public need for ecological safety and wellbeing is satisfied [1]. Synthetic character of modern ecology and its orientation towards satisfying vital needs make involving of youth into ecology problem situations inevitable, regardless of their life or professional choices.

The above-stated assertions allow us to say that a modern young person, which aspires for success in professional and personal life, should be able to act effectively and ecologically in problem situations, which arise in different areas of activity, and find the only right solution. Such a conduct requires certain attitude.
In view of this, forming such a trait among senior pupils as self-determination within ecology problem situations, in which they are to assess, define or alter their attitude towards this particular situation, that is to self-determine, can be considered one of the most revelant tasks of modern education.

Self-determination of senior pupils in the ecology field is an individually valuable activity aimed at analysis, elaboration or formation of a subjective attitude towards ecology problem situations and activity performed for the purpose of solving them.

It brings us to the conclusion that self-determination is a kind of activity that results in the formation of an attitude to ecology problem situations.

Ecology activities are socially-oriented, as their results from ecology awareness among senior pupils and society as a whole and give its members a lead towards elaborating and forming an active living position providing a responsible attitude to nature and own health.

The ecology-related activity of senior pupils stimulates gaining experience in formation and establishment of own attitude to various real-life situations while facilitating the development of cognitive interest, theoretical conscience, and knowledge, which become the basis for further professional growth [2].

Inclusion of senior pupils in a situation of choice of profession as subjects of self-determination makes consciousness active and leads to emergence of professional consciousness in its structure that, according to P.A. Shavir, is the most important new formation of youth age, which is needed for psychological readiness of a younger generation for independent work [3].

Thus, the peculiarities of psychological development of youth allow us to consider ecology self-determination as an important aspect of social becoming of senior pupils. What is more, this period of education is the most 
efficient one for the formation of ecology selfdetermination.

From our point of view, these opportunities will only be realized when senior pupils' activity implying ecology self-determination is considered to be not only an efficient way of learning which ensures fundamental knowledge and forms responsible attitude to Nature and health but also as the self-sufficient purpose of general education.

While being educational, the ecology-related activity of senior pupils has its own peculiarities that differ them from those ones related to other areas. It is due to the interdisciplinary character of ecology and the fact that results of ecology-related activity carried out by senior pupils are socially important and possess objective novelty peculiar to scientific researchers. Involving senior pupils in activity in the field of ecology forms such socially important quality of a person as ecological consciousness directly at trained, forms a certain attitude of society members to Nature and providing formation at a younger generation of active living position in the field of ecology.

So, $63 \%$ of senior pupils who completed ecological projects as part of the educational process claimed that their relatives, friends and acquaintances showed interested in this work, and $18 \%$ of senior pupils said that during accomplishing projects adults would often offer their help.

Peculiarities of ecology-related activity of senior pupils imply that its results can be used to solve local ecology problems that are of social importance (such as solid domestic waste issue, homeless animals issue, woodland protection, etc.). According to senior pupils, the greatest interest in people was caused by projects directed to the solution of environmental issues connected with the place of residence of these people. Such an interest from the next and therefore personally significant social environment of senior pupils to their activity creates favorable conditions for formation of the structure of their identity, of readiness for development and upholding of a personal position in the sphere of ecology. The survey that we have conducted among senior pupils in Moscow proved that $61 \%$ of senior pupils involved their classmates or adults that were important for them into their ecology project work. Nevertheless, senior pupils revealed an understanding of the importance of activities in the ecology field to society. Although only $8 \%$ of respondents mentioned their previous experience in ecology-related activities, $38 \%$ of senior pupils were certain to consider personal attitude necessary for the successful solution of ecology problems.

Self-determination as an activity is initiated by problem situations that require senior pupils to define (alter or form) a personal attitude, that is an act of selfdetermination. Thus, problem situations in the ecology field should be considered as triggering selfdetermination.

Performing different activities (training, gaming, research, nature conservation, etc.) in ecology field, senior pupils are being involved in problem situations of selfdetermination.
Analysis of psychological and pedagogical literature allows us to consider a senior pupil who shows readiness for self-determination in the ecology domain as a person capable of carrying out analysis, defining (correction) and forming of a certain attitude while detecting, analyzing and solving ecology-related problem situations that arise during performing socially important activities.

Readiness as a trait which implies knowledge, skills and attitude to certain activity is a functional state of a personality, the result of psychological processes that precede this activity $[4$, p.9].

Therefore, the readiness of senior pupils for selfdetermination can be regarded as an ability to form a certain attitude while defining, analyzing and solving problem situations in the ecology field.

Emotional attitude to any ecology-related situation that is manifested by basic emotions, namely interest, is a special component of senior pupils' readiness for selfdetermination. Being involved in an ecology-related situation, a senior pupil is not indifferent. Such an emotional attitude manifests itself in "conscious and unconscious union of a person and nature, its harmony and integrity', in 'feeling pain', in 'suffering from its inferiority, from its harmony and beauty being destroyed', that B.T. Likhachev puts as 'ecological feeling'. Without emotional component, a senior pupil's attitude towards ecology-related situations will 'not have stimulating function' [5].

Initiative attitude to any situation in the ecology field is an important part of senior pupils' readiness for ecology-related self-determination and is manifested in a willing, voluntary participation in an ecology-related situation as an actor, in willingness to find information about this situation, in willingness to solve this ecological issue successfully. Attitude towards practical ecology activities is, according to I.D. Zverev, one of the components that signify well-formedness of responsible personal attitude in the ecology field [6], which makes up the basis of a senior pupil's ecology-related attitude.

One of the most crucial tasks of ecological education is forming a system of scientific and practical knowledge. That is why systematic knowledge of structure and interrelations between living systems (species, populations, communities, biosphere living matter) and environment; of impact made by industry and consumption on living systems and of ways to make up for this impact; of principles of social relations that are somehow related to ecology and health issues and manifested in involving senior pupils into ecology-related situations as actors should be considered the most important component of senior pupils' readiness for self-determination in the ecology field.

A crucial aspect of this readiness is the social and personal importance of ecological activities that manifest themselves in the ability to explain its importance and significance for a person and society as a whole, in the willingness to be involved in it and doing so.

This trait is defined by the fact that personal attitude in the ecology field will be formed and actualized only if senior pupils realize the importance of the results of their ecology-related activity. In other words, a personal attitude in the ecology field will be formed only when 
knowledge of senior pupils about the social and personal importance of such activities forces them to gain the positive attitude towards their activities and realize that they are part of interrelations in the ecology field.

Knowledge about social and personal importance of self-determination of senior pupils in the ecology field is connected with their understanding of own capabilities and skills in planning and performing activities aimed at solving problem situations in the ecology field and capabilities in terms of performing new kinds of activities that are manifested in reasonable assessment of own capabilities of rational planning and performing own activities.

From the practical perspective, mental activity based on intellectual operations of reproductive, productive and heuristic types that ensure the formation of a certain attitude while defining, analyzing and solving ecologyrelated problem situations that arise during performing various kinds of socially important activities, should be regarded as a core part of readiness.

Considering structure of readiness of seniors for selfdetermination in the field of ecology, as the purpose of pedagogical process it is possible to consider formation at senior pupils:

- emotional and initiative attitude to any ecologyrelated problem situations that arise while performing various kinds of socially important activities, which is the need-motivational component of readiness for analysis and defining (correction, formation) senior pupils attitude;

- systematic ecological knowledge about the social and personal importance of activities in the ecology field and of own capabilities to solve ecology-related problem situations, which is a cognitive component of senior pupils' readiness to form personal attitude;

- the ability to define, analyze and solve problem situations in the ecology domain based on intellectual operations of reproductive, productive and heuristic types, which ensure forming a certain attitude while performing various socially important activities that comprise the practical component of readiness.Having defined the well-formedness of each component, in particular, the general level of readiness can be assessed, which makes it possible to use them as criteria for determining the readiness of senior students' for self-determination in the ecology domain.
The complex character of the pedagogical process aimed at forming in senior pupils readiness for selfdetermination in the ecology field makes it possible to consider this process in three aspects that can be compared to a coordinate system of three dimensions corresponding to the need-motivational aspect, the cognitive aspect and the practical aspect of readiness.

All components of senior pupils' personal trait in question are equally important, and if any of them is poorly formed, it makes the achievement of pedagogical goals impossible. Nevertheless, the core or framework component is the practical one. That is why the process of forming readiness for self-determination in the ecology field in senior pupils can be regarded as series of inter-related problem situations in the ecology field in which senior pupils are involved as actors and which imply analysis, defining and forming of attitude in the ecology field.

\section{References}

1. I.D. Zverev, Prioritety ekologicheskogo obrazovaniya (MNEPU, Moscow, 1995) [In Rus]

2. M.S. Kagan, Chelovecheskaya deyatel'nost' (opyt sistemnogo analiza) (Politizdat, Moscow, 1974) [In Rus]

3. B.T. Likhachev, Filosofiya vospitaniya. Spetsial'nyi kurs (Prometei, Moscow, 1995) [In Rus]

4. T.L. Mironova, Samosoznanie professionala (BSU, Ulan-Ude, 1999) [In Rus]

5. E.V. Titov, Teoriya i praktika formirovaniya gotovnosti starsheklassnikov $k$ issledovatel'skoi deyatel'nosti v sfere ekologii (Taganka, Moscow, 2003) [In Rus]

6. S.N. Chistyakova, and A.Ya. Zhurkina, Kriterii $i$ pokazateli gotovnosti shkol'nikov $k$ professional'nomu samoopredeleniyu (Filologiya, Moscow, 1997) [In Rus] 